\title{
GEOPOLITICAL SITUATION OF UKRAINE AND ITS IMPORTANCE
}

\section{Bálint STÖRK}

National University of Public Service, Budapest, Hungary, Faculty of Military Sciences and Officer Training, Military Leadership (BSc), Reconnaissance Specialisation

Keywords: Ukraine, Geopolitics, Military, Strategy, Russia, Europe.

\section{Introduction}

Ukraine's importance points beyond the fact that this area is Europe's second largest state in area and the largest part of it dominates the East European Plain. Its geopolitical position has an important role in Europe. But what is geopolitics? Why do we need to clarify this term?

Because, throughout history, scientists have defined this from various aspects from the geographical, historical, political, anthropological, geo-historical, military-geographical and geostrategical point of view.

The word itself originates from the Greek. Geos (Earth) and politicos (community) and represents a politically relevant community's power through the state over a geographical area.

According to the accepted modern definition: 
"Geopolitics is a multidisciplinary science which analyses the international relations."

In my paper, I want to examine the geopolitical situation of Ukraine from a historical, socio-geographical, military-geographical and geostrategical point of view; thus providing a deeper insight into the region. Furthermore, I would like to focus on the root of the region's problems and issues that might arise.

\section{History of Ukraine}

The word "ukraine" comes from the russian okraina, the ukrainian krójiny and the hungarian karéj words. The meaning is something's edge or border and, throughout history, it was indeed a borderland.

Unfortunately, through the centuries, foreign armies struck the the area, which had an effect on people's culture and affiliation.

\section{9-10th century (Kievan Rus)}

Ukraine's official history regards the beginning of the country as the establishment of the Kievan Rus which united Eastern Slavs.

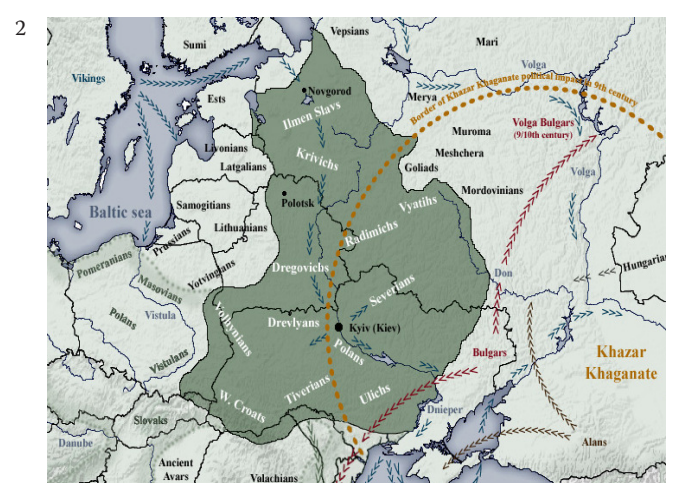

The rulers succesfully fought against neighbouring tribes and were able to secure their power in the region so the nation could start growing.

The area was situated on the western side of Russia, Belorussia and today's Ukraine central and western territory.

1 István Szilágyi:Geopolitics (ISBN:978-615-5001-74-1) page 11.

2 http://upload.wikimedia.org/wikipedia/commons/8/89/East_Slavic_tribes_peoples_ 8th_9th_century.jpg Downloaded: 2015.05.27. 


\section{1th century}

The Kievan Rus reached its golden age in the 11th century with its area spreading from the Baltic Sea to the Black Sea.

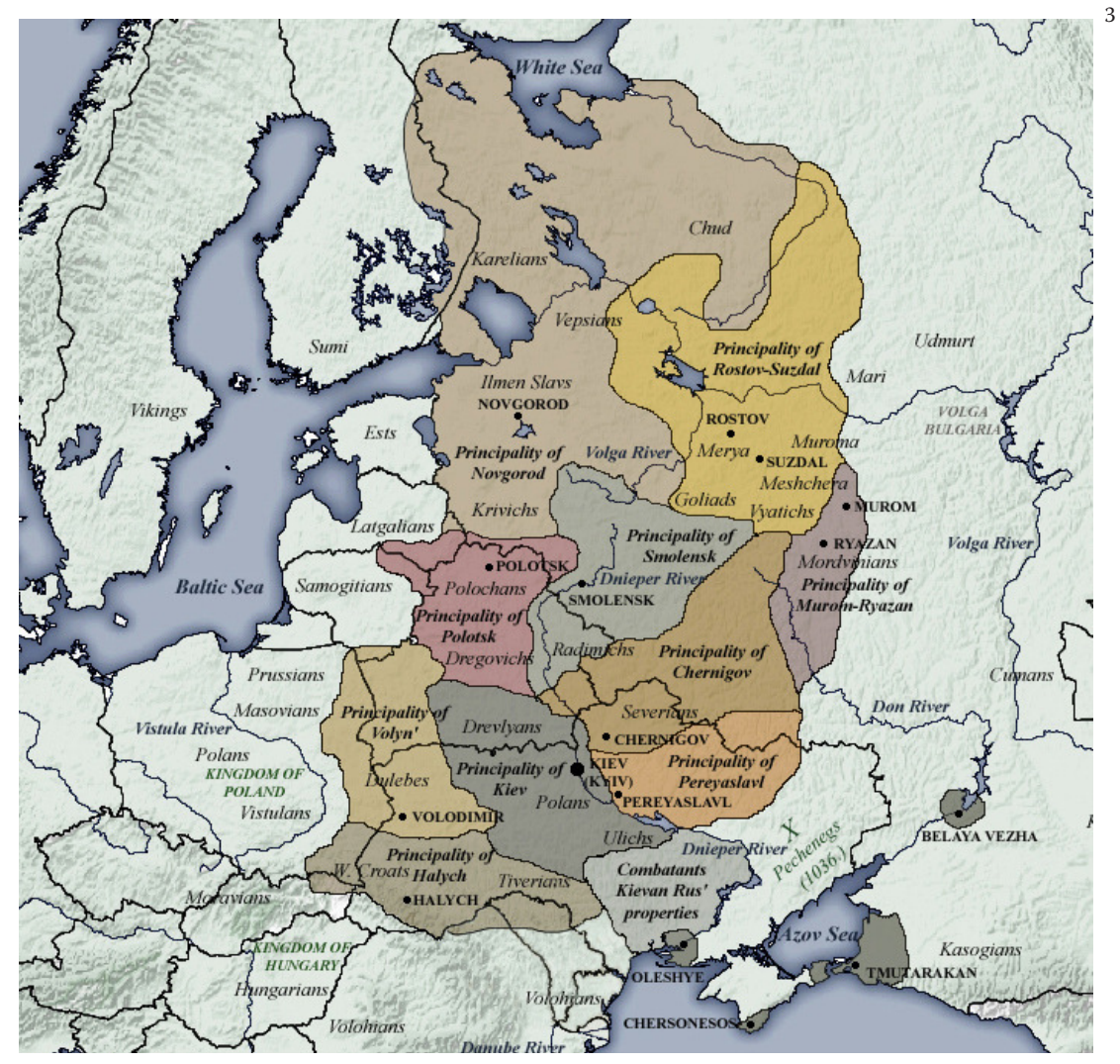

The most sighnificant ruler was Yaroslav the Wise (978-1054) who secured his power through dynastic relations with French, Byzantine, Norwegian, Hungarian and Polish families

After his death, his empire was divided among his sons, which led to the fall of the nation due to clan wars.

3 http://upload.wikimedia.org/wikipedia/commons/d/db/Principalities_of_Kievan_ Rus\%27_\%281054-1132\%29.jpg Downloaded: 2015.05.27. 


\section{2th century}

The Mongols and the Tatars conquered the vast majority of the country and it was torn apart leaving it in independent parts with separate politics.

\section{3-14th century}

In the fights against the Mongols, the northern and western part came under Polish-Lithuanian rule.

The locals were forced to adopt the Catholic faith which led to religious and ethnic conflict among the population.

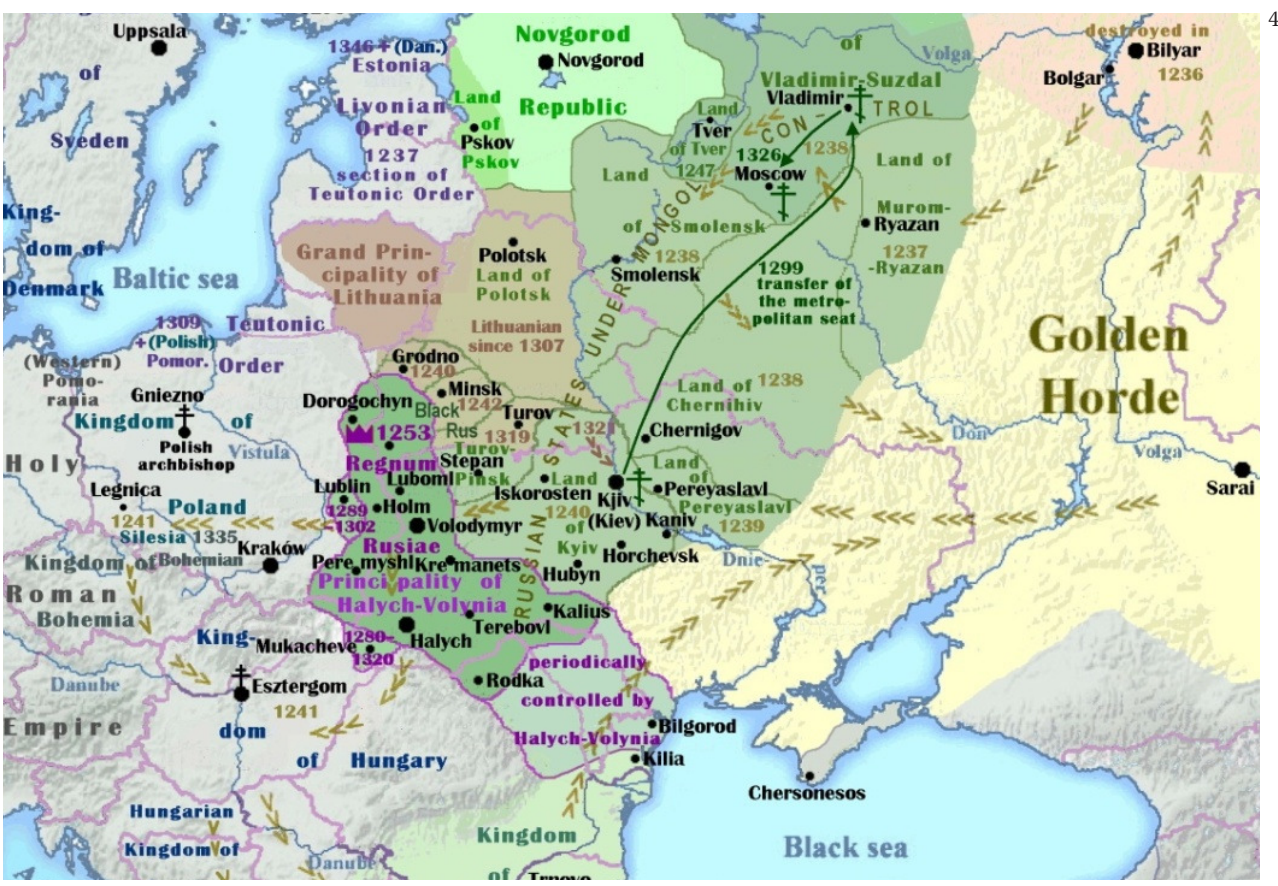

4 http://upload.wikimedia.org/wikipedia/commons/4/43/Kingdom_of_Galicia_ Volhynia_Rus\%27_Ukraine_1245_1349.jpg Downloaded: 2015.05.27. 
Southern Ukraine was inhabited by cossacks and the greek catholic, slavic folks fled from Russia. The Zaporozhia Cossacks form part of today's Ukrainian identity. Crimea was under the rule of the Crimean Khanat.

Ukraine's southern parts, including the Crimean Penninsula, were overwhelmed by the Golden Horde, and following that it came under rule of the Crimean Khanat.

\section{5-16th century}

The Polish-Lithuanian commonwealth spread its influence and the Greek Catholic church became slowly dominant. The Zaporozhia Cossacks were ruled by the hetman (military leader).

In the upcoming centuries, they were fighting with the neighbouring nations (Poles, Lithuanians, Russians).

\section{7th centrury (Cossack Era)}

The Cossack hetman, Bogdan Khmelnytsky, led a rebellion in 1648 and freed Kiev and other parts of today's Ukrainian Cossack state.

In 1654, Khmelnytsky signed the Treaty of Pereyaslav with the Russian Tsar. Under its terms, Ukraine was united with Russia. 


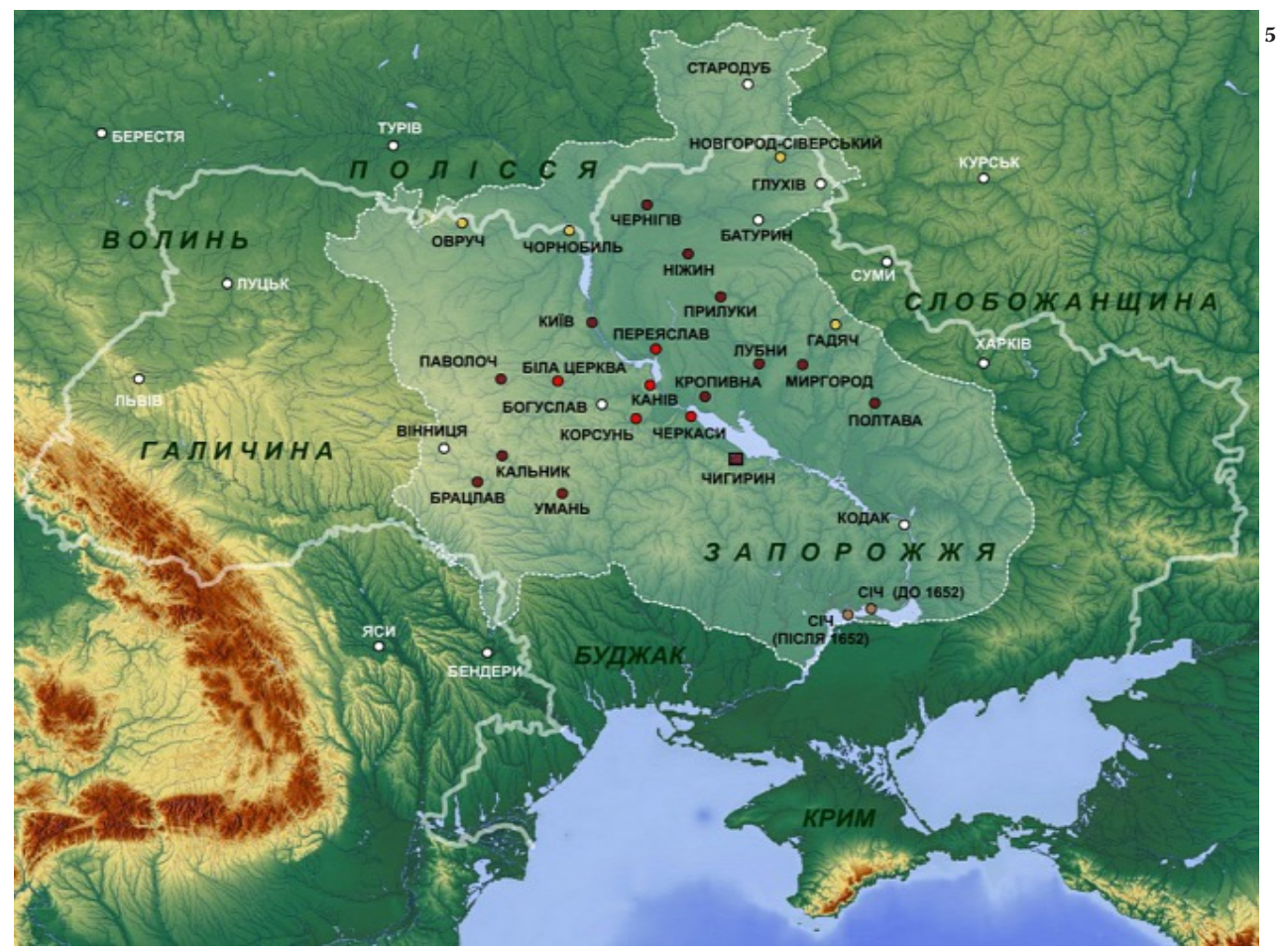

Fighting continued and, in 1667 (Truce of Andrusovo), Russia and Poland partitioned Ukrainian territory along the River Dnepr:

- Left Bank remained under Russian control

- Right bank returned under Polish control
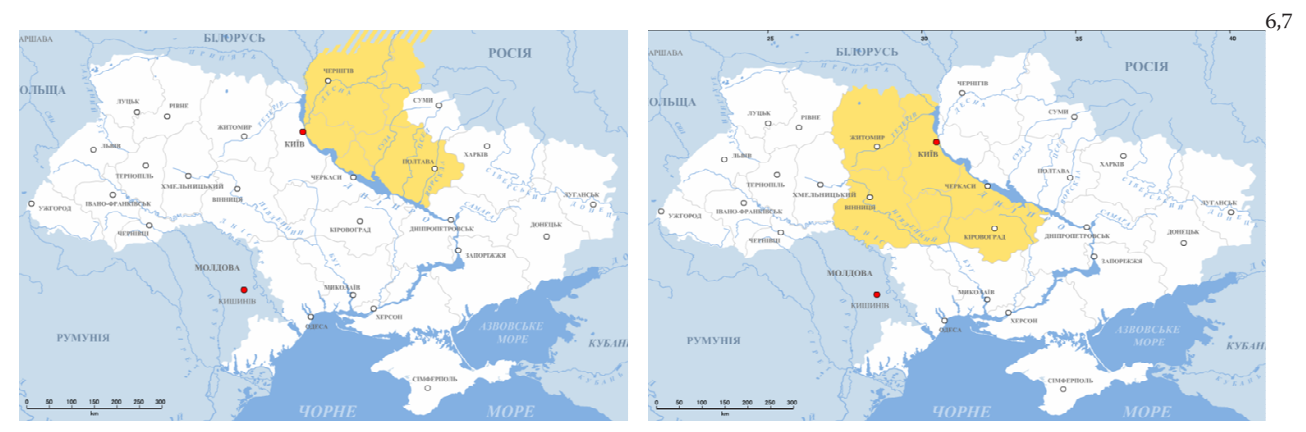

5 http://upload.wikimedia.org/wikipedia/commons/5/56/Location_of_Cossack_ Hetmanate.png Downloaded: 2015.05.27.

6 AlexTora:"Ukraine-Pravoberezzhya"http://commons.wikimedia.org/wiki/File:UkrainePravoberezzhya.png\#/media/File:Ukraine-Pravoberezzhya.png Downloaded: 2015.05.27.

7 Alex Tora "Ukraine-Livoberezzhya", http://commons.wikimedia.org/wiki/File:UkraineLivoberezzhya.png\#/media/File:Ukraine-Livoberezzhya.png Downloaded: 2015.05.27. 


\section{8th century}

The Polish Kingdom had entered a period of decline, so the neighbouring big nations (Austria, Russia) wanted to acquire its territories:

- Russia expanded it's territory, integrated the Cossacks and settled Russian peasants on the newly acquired Crimea

- The Austro-Hungarian Empire annexed Western-Ukraine (East-Galicia)

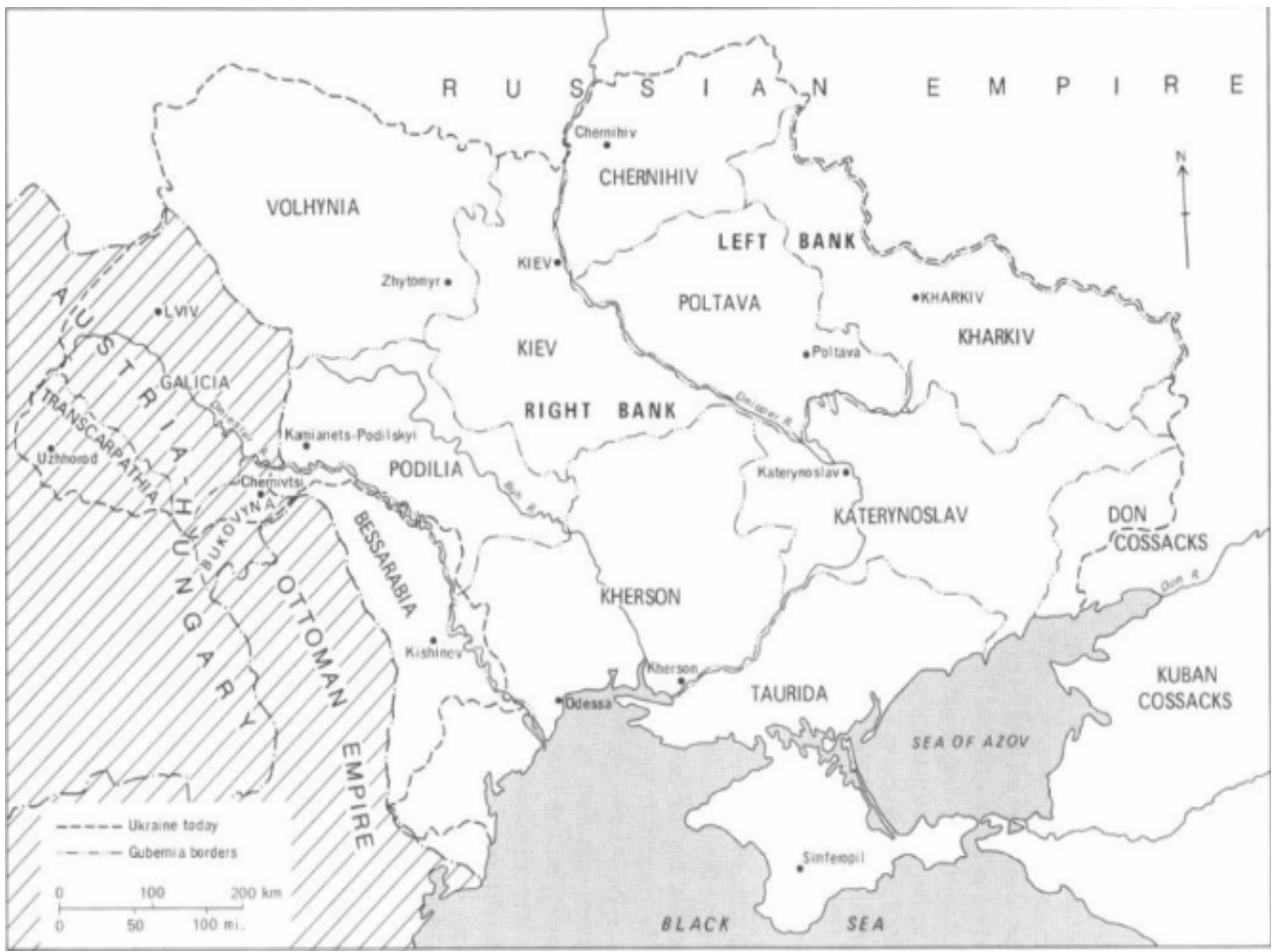

\section{0th century}

After the end of the first World War, a movement for Ukrainian independence emerged, but thebolsheviks gained power and it was later absorbed into the Soviet Union. Ukraine was repartitioned by the 1921 Treaty of Riga:

Eastern Ukraine was incorporated into the USSR, while Western and Eastern Galicia returned to Poland. 
(Soveit rule brought Ukraine rapid industrialisation, urbanisation and collectivisation.)

In September 1939, in accordance with the secret protocols of the Molotov Ribbentrop Pact, the USSR invaded Eastern Galicia.

After the Second World War, Eastern Galicia remained within the USSR, while Western Galicia was returned to Poland.

In 1954, Khrushchev gave Crimea to Ukraine.

After the dissolution of the Soviet Union, Ukraine became an independent Republic (December 1991)

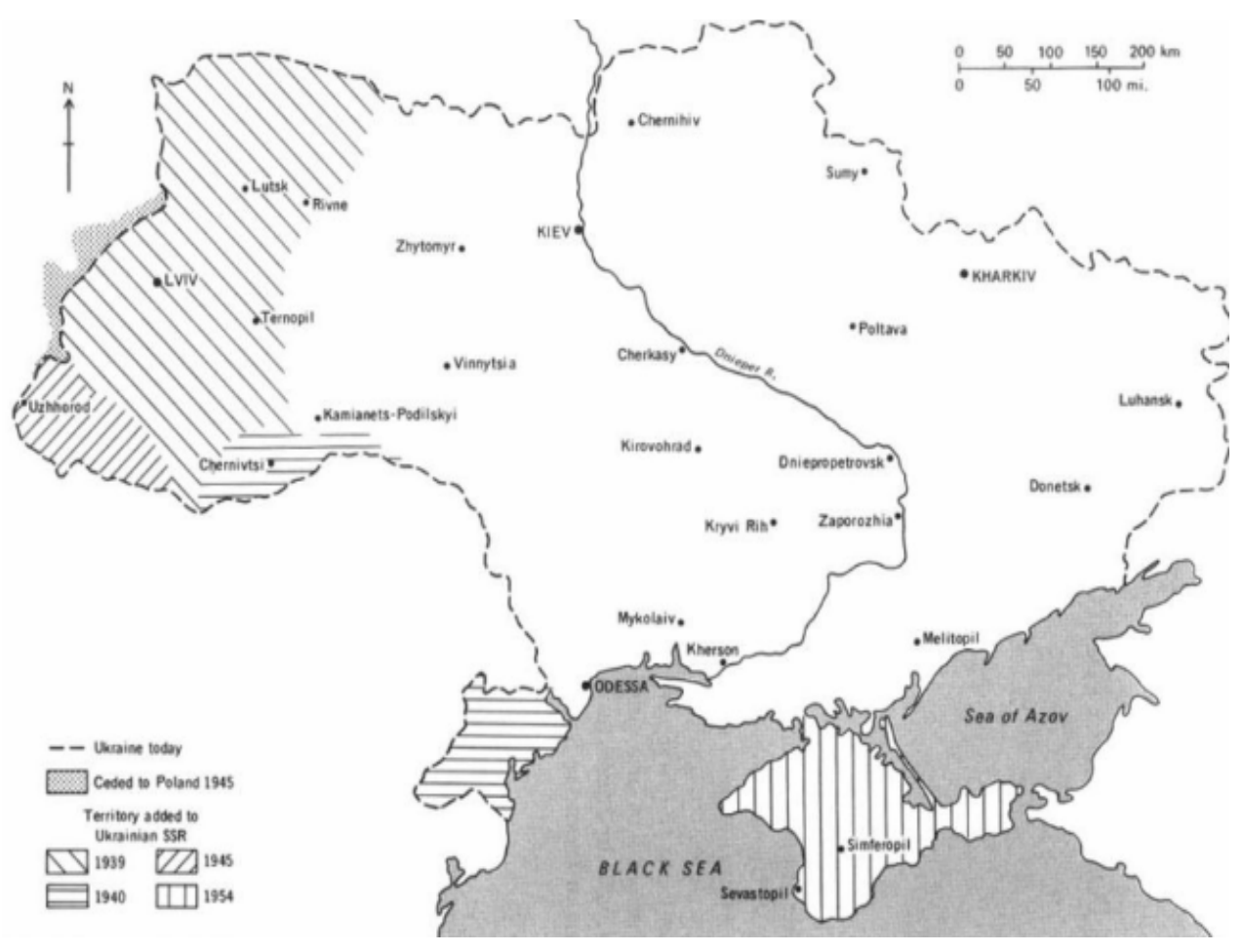




\section{Conclusion I}

- Ukrainian independence was against the neighbouring powers

- Continuous rivalry of catholic Poland and orthodox Russia influenced society

- By the end of the 17th century:

- Eastern part: Russian dependence

- Western part: Polish influence

- Southern part: Tatars, later Zaporozhia Cossacks

- Middle part: ancient kievan Rus and Helmetcky territory

\section{Conclusion II}

- By the end of the 19th century (for more than 150 years)

- 80 percent russian

- Ukrainian language was banned

- 20 percent Habsburg

- Aided ukrainian culture

- 20th century:

- rapid industrialisation, urbanisation and collectivisation

\section{Regional geography}

The country is officially and legally a unitary republic. 


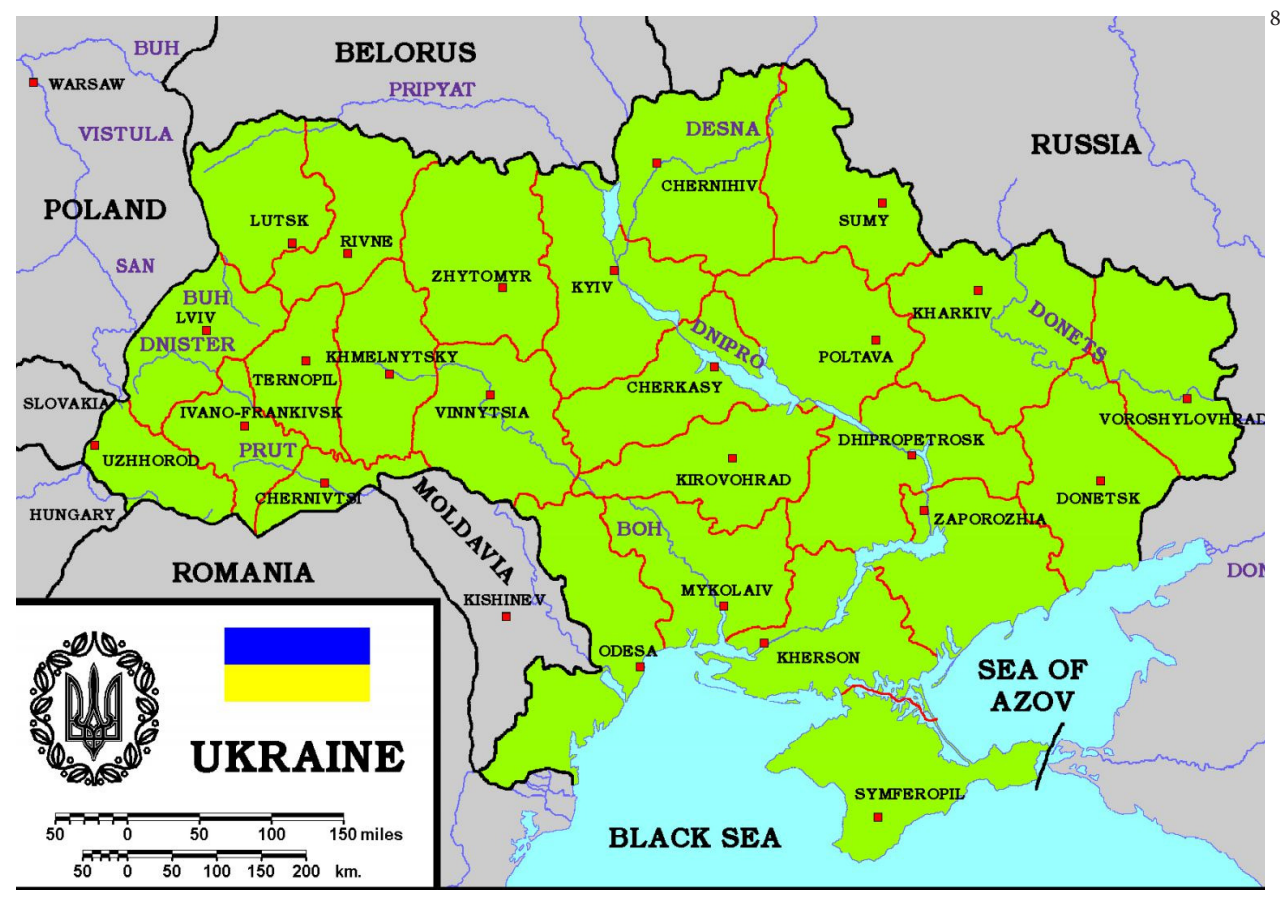

With 24 administrational regions (oblast) ${ }^{9}$

1) Cherkasy Oblast

2) Chernihiv Oblast

3) Chernivitsi Oblast

4) Dnipropetrovsk Oblast

5) Donetsk Oblast

6) Kharkiv Oblast

7) Kherson Oblast

8) Khmelnytskiy Oblast

9) Ivano-Frankivsk Oblast

10) Zakarpattya Oblast

11) Kirovohrad Oblast

8 http://www.ukrexport.gov.ua/i/imgsupload/image/administrative.jpg Downloaded: 2015.05.20.

9 In 2014, Before the annexation of Crimea and the separation of Luhansk, Donetsk oblasts. 
Kyiv city )

12) Kyiv Oblast -

Autonomos Republic of Crimea

13) Luhansk Oblast

14) Lviv Oblast

15) Mykolayiv Oblast

16) Odesa Oblast

17) Poltava Oblast

18) Rivne Oblast

Sevastopol city

19) Sumy Oblast

20) Ternopil Oblast

21) Vinnytsya Oblast

22) Volyn/Lutsk Oblast

23) Zaporizhya Oblast

24) Zhytomyr Oblast

We can distinguis 3 major regions:

- Western-Ukraine

- Central- Ukraine

- South-East Ukraine.

Among important factors, we can mention historical, geopolitical, ethnical, linguistical, economical ones.

Ukraine has high quality soil on its eastern, south-eastern part, which made Ukraine the largest crop producing country. The excessive development of heavy industry made the country the second most significant member of the Soviet Union.

From this, we can clearly see that the homogenity of the country is just an illusion. Neither society nor the identity of the regions are unified. 


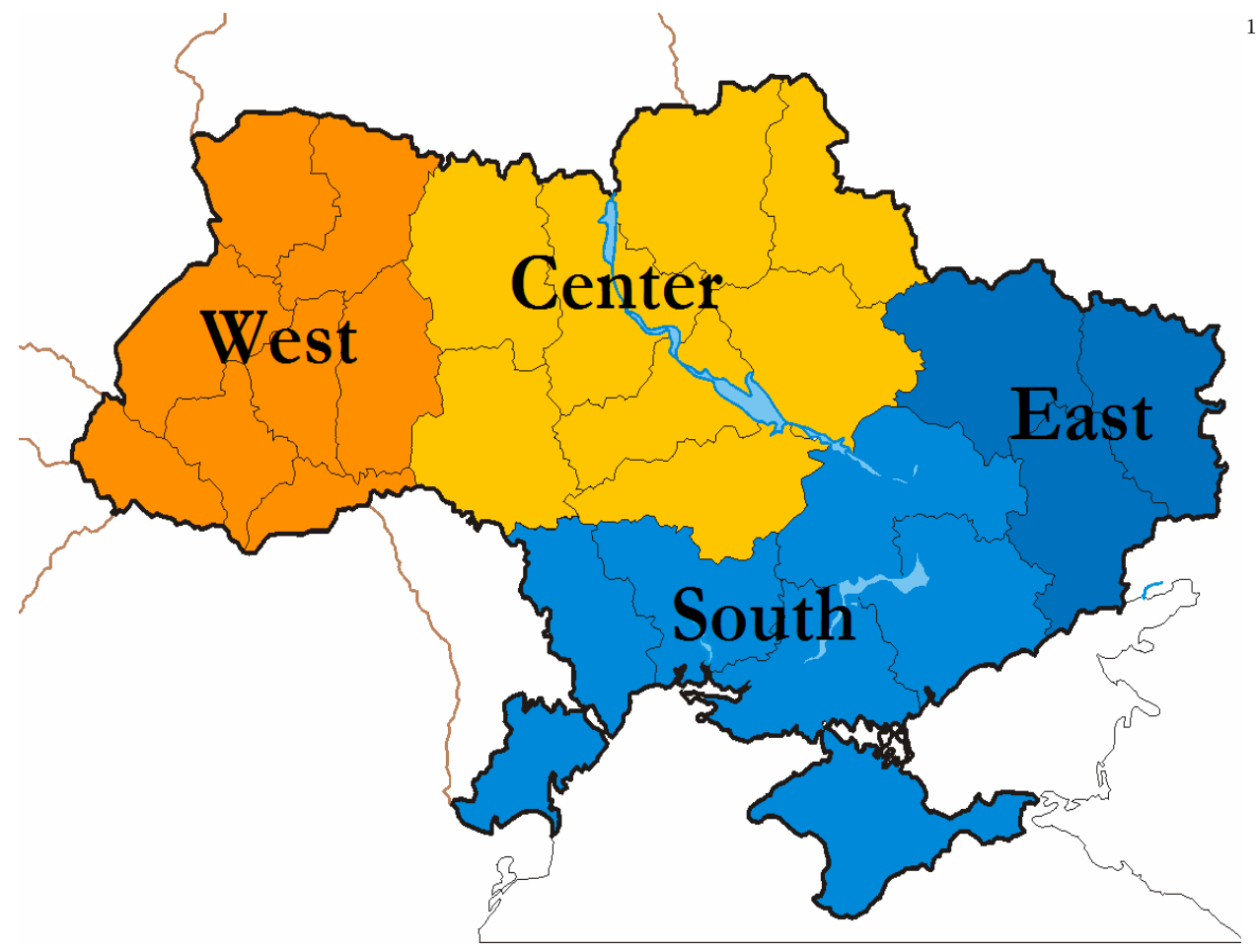

Socio-geography

The form of government is a Constitutional Republic

Official language is Ukrainian.

Population is 42.89 millon (2015)

Density is $73.8 / \mathrm{km}^{2}$

Ethnical composition of the society:

- Ukrainian77,8\%,

- Russian 17,3\%,

- Polish 4\%,

10 http://upload.wikimedia.org/wikipedia/commons/a/af/Ukraine_KIIS-Regionaldivision2.png Downloaded: 2015.05.27. 
- Jewish 1\%,

- Hungarian 0,3\%,

- Moldovan 0,6\%,

- Belorussian 0,8 \%,

- Other (Tatar, Romanian) 7\%.

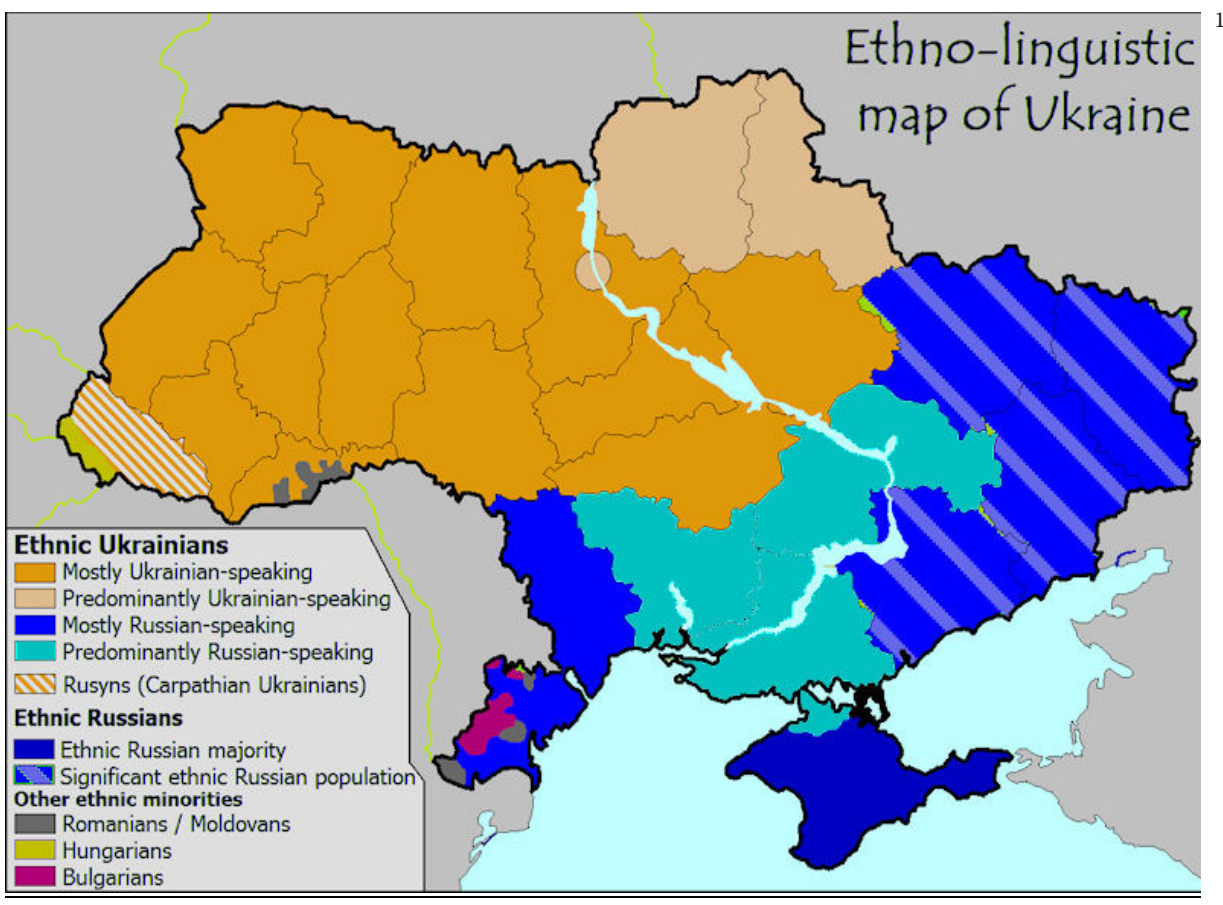

\section{Religious composition of society:}

- Orthodox 70\%

- Greek Catholic 13\%

- Roman Catholic $2 \%$

- Hebrew 1\%,

- Other $7 \%$

11 http://www.globalsecurity.org/military/world/ukraine/images/map-ethno-linguistic. jpg Downloaded: 2015.05.20. 


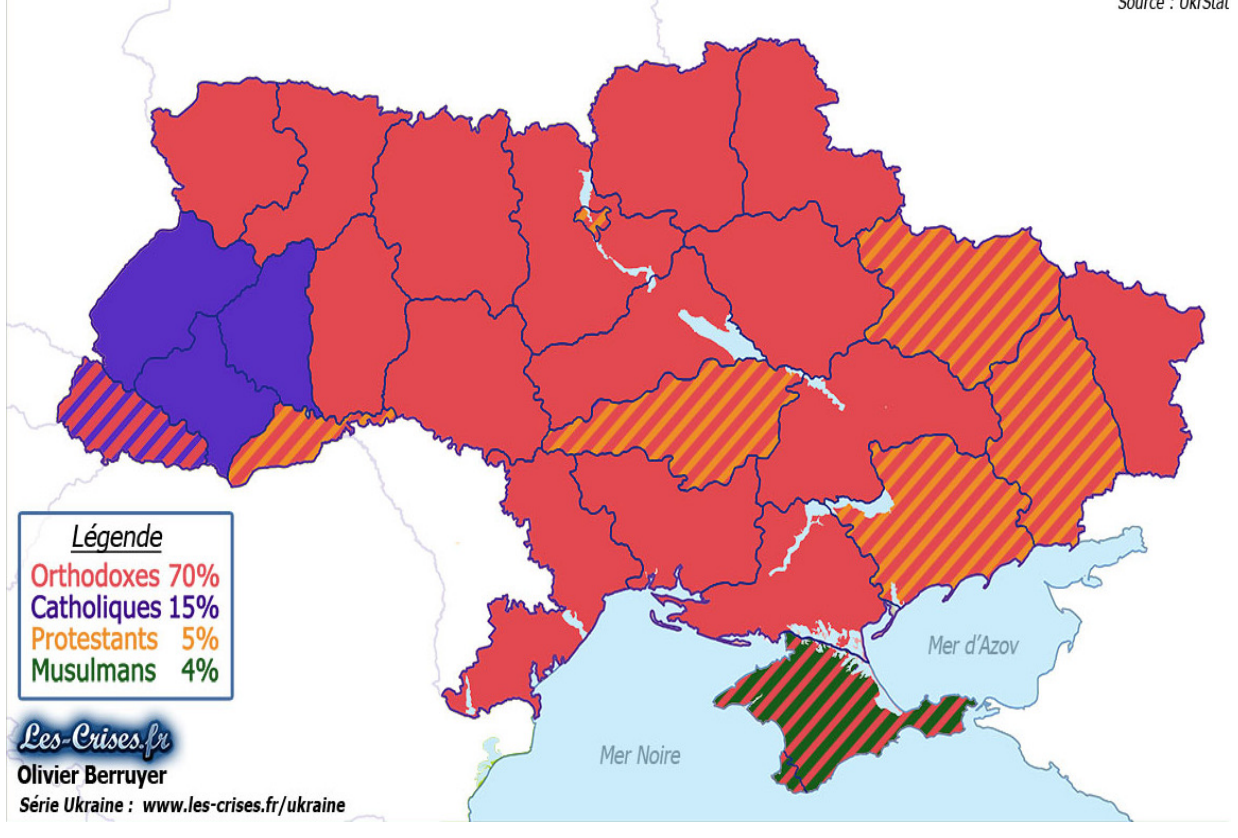

We can see that, on the western territories, catholicism is dominant, mainly due to the Polish influence.

\section{Military Gerography}

Because of its geographical situation, Ukraine contributes to regional stability and to European Security.

As NATO has expanded towards the east, the significance of the region has increased.

Like Russia, Ukraine inherited a seemingly impressive military establishment from the Soviet Union. While the military has been downsized and partially rationalised, it remained fundamentally unreformed.

12 http://www.les-crises.fr/images/3100-democratie/3500-ukraine/01-les-faits/01-3population/31-religions-ukraine.jpg Downloaded: 2015.05.27. 
Amred Forces of Ukriane:

- Ground Force

- Air forces

- Navy

In the picture below, we can see the structure of the armed forces.

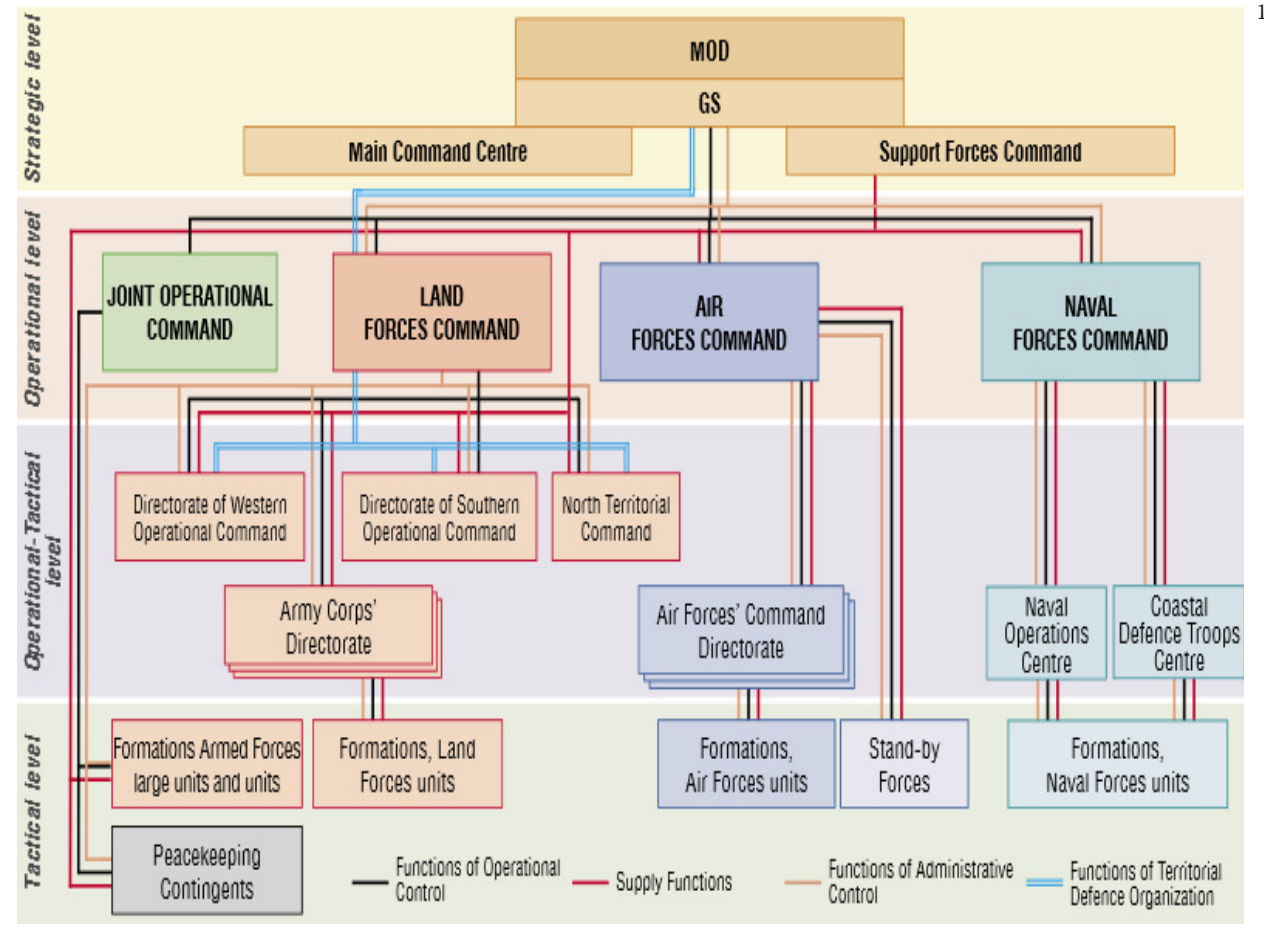

The highest decision making body is the Ministry of Defence.

13 https://web.archive.org/web/20080910033843/http://www.mil.gov.ua/files/white_ book/white_book_en2007.pdf Downloaded: 2015.05.20. 


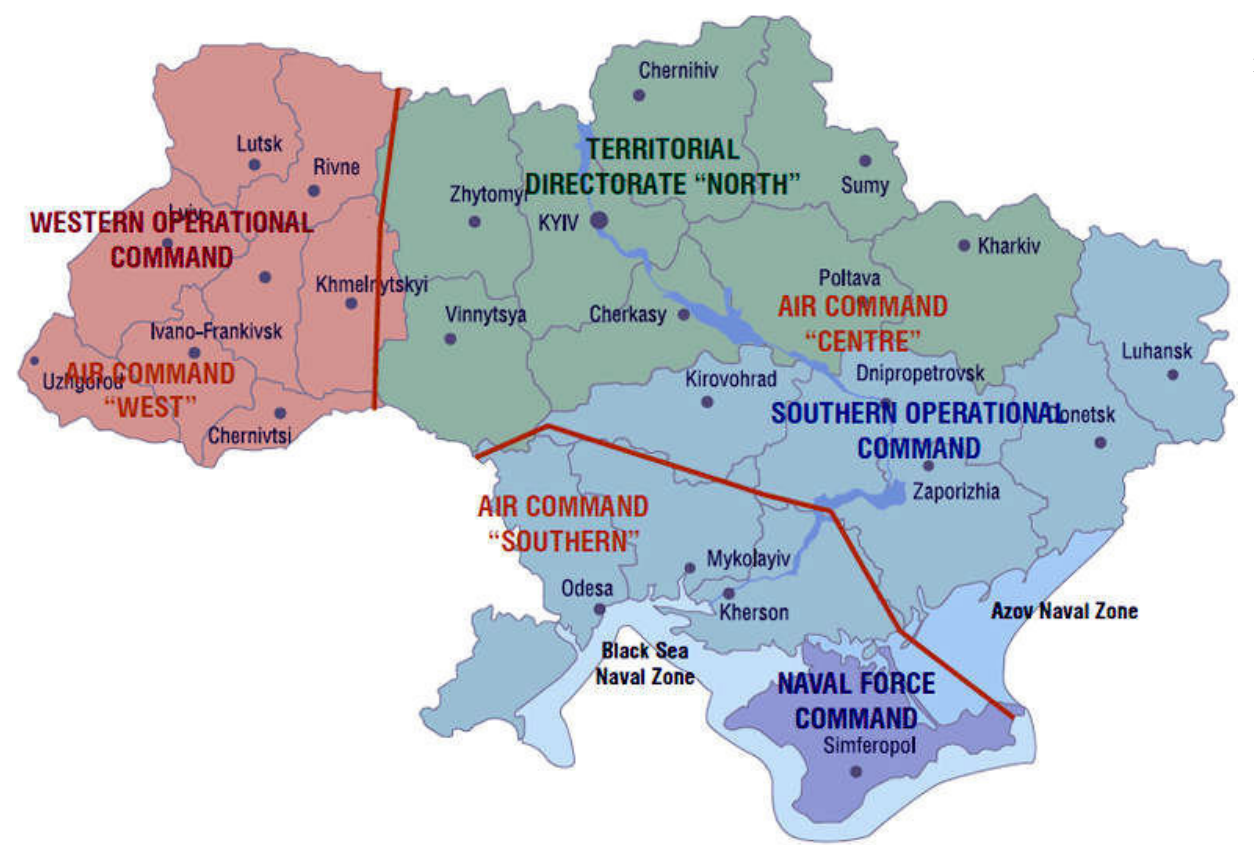

\section{Ground forces}

3 territorial commands:

- Western Operational Command

- Terriotorial Directorate "North"

- Southern Operational Command

Has three Corps:

- 13th Army Corps

- 6th Army Corps

- 8th Army Corps (Rapid Reaction)

14 http://www.globalsecurity.org/military/world/ukraine/images/map-ukrainecommands-2006.jpg Downloaded: 2015.05.20. 


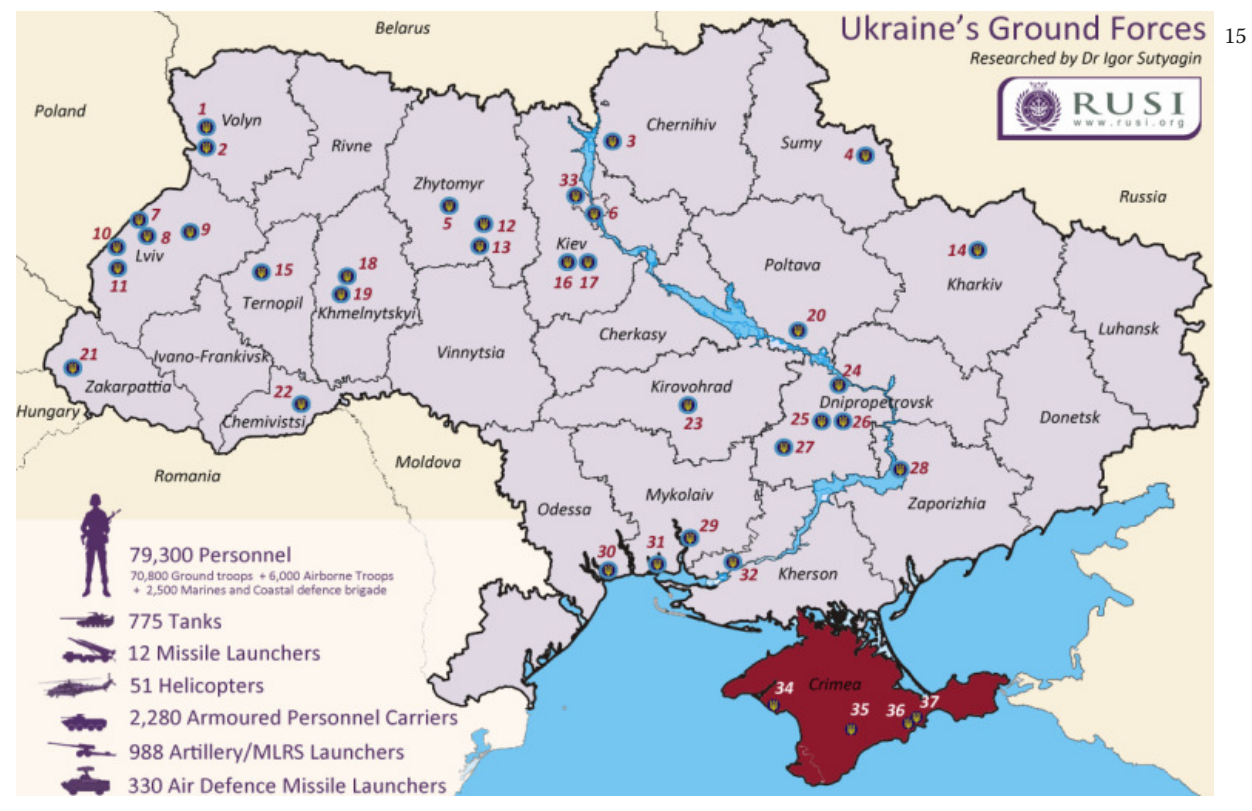

The official units in march 2014:

1) 51 st mechanised brigade, Vladimir-Volynskiy

2) 59th zenith-rocket (Air defence) regiment, Vladimir-Volynskiy

3) 1st tank brigade, Goncharivske

4) 27th rocket-artillery (MLRS) regiment, Sumy

5) 30th mechanised brigade, Novograd-Volynskiy

6) 1st Special Operations (Spetsnaz) regiment, Kiev

7) 24th mechanised brigade, Yavoriv

8) 80th air-mobile regiment, Lviv

9) 16th Army aviation brigade (helicopters), Brody

10) 7th Army aviation regiment (helicopters), Kaliniv

11) 15th artillery regiment, Drogobych

12) 95 th air-mobile brigade, Zhitomyr

13) 26th artillery brigade, Berdichiv

15 Igor Sutyagin and Michael Clarke: Royal United Service Institute: Briefing Paper, Ukraine Military Disposition (March, 2014) Downloaded: 2015.05.27. 
14) 92nd mechanised brigade, Klugoshino-Bashkirivka

15) 11th artillery brigade, Ternopil'

16) 72nd mechanised brigade, Belaya Tserkov'

17) 1129th zenith-rocket (Air defence) regiment, Belaya Tserkov'

18) 8th Special Operations (Spetznaz) regiment, Khmelnitskiy

19) 19th missile brigade, Khmelnitskiy

20) 107th rocket-artillery (MLRS) regiment, Kremenchukh

21) 128th mountain infantry brigade, Mukachevo

22) 300th mechanised regiment, Chernivtsi

23) 3rd Special Operations (Spetsnaz) regiment, Kirovohrad

24) 93 rd mechanised brigade, Chirkass'ke

25) 1039th zenith-rocket (Air defence) regiment, Khvardeyske

26) 25th airborne brigade, Khvardeyske

27) 17th tank brigade, Krivoy Rog

28) 55th artillery brigade, Zaporizhzhya

29) 79th air-mobile brigade, Mykolaiv

30) 28th mechanised brigade, Chornomor'ske

31) 73rd Naval Special Operations (Spetsnaz) Centre, Ochakiv

32) 11th Army aviation regiment (helicopters), Chornobaivka

33) 101st Houseguards brigade, Kiev

34) 55th zenith-rocket (Air defence) regiment, Evpatoriya

35) 36th coastal defence brigade, Pereval'ne

36) 801st Naval Special Operations (Spetsnaz) battalion, Feodosiya

37) 5th Marine battalion, Feodosiya (belongs to the 36th Coastal defence brigade

\section{Air Force}

3 air commands:

- Air Command "West"

- Air Command "Centre"

- Air Command "Southern"16

16 http://www.globalsecurity.org/military/world/ukraine/images/map-vps-bases.jpg Downloaded: 2015.05.20. 
Main airbases in 2014:

- (Kolomyla)

- (Vinnitsa)

- (Stratokostlantyniv)

- (Vasylkiv)

- (Mirgorod)

- (Zaporizhia)

- (Kubalkino)

- (Meltopol)

- (Belbek) After the annexation of the Crimean Penninsula, the base came under Russian rule. The Ukrainian Air Force has received the unit's aircraft back.

Aircraft according to units:

- 5 brigade (air superiority fighter): Mig-29 Fulcrum, Su-27 Flanker

- 2 brigade (air superiority fighter, attack): Su-24 Fencer, Su-25 Frogfoot

- 2 squadron (Electronic reconnaissance): Su-24 MR Fencer E

- 3 brigade (transport): An-24, An-26, AN-30, Il-76 Candid, Tu-134 Crusty

- 2-3 squadron (trainer): L-39 Albatros

- 2-3 squandron (transport helicopter) Mi-8, Mi-9, PZL Mi-2 Hoplite

Aircraft according to type

Fixed wing: 221

- air superiority fighter: 126 :

- 90 Mig-29 Fulcrum

- $36 \mathrm{Su}-27$ Flanker

- ground attack: $36 \mathrm{Su}-24$ Fencer

- attack: $36 \mathrm{Szu}-25$ Frogfoot 
- ISR (electronic reconnaissance): 26

- 3 AN-30 Clank

- 23 Stu-24 MR Fencer E

- Transport:46

- heavy transport: 20 Il-76 Candid

- light transport: 26

- 3 An-24 Coke

- 21 An-25 Curl

- 2 Tu-134 Crusty

- Trainer: 39 L-39 Albatros

Helicopter:

- Command and Control (C2): 4 Mi-9

- Transport: 34

- Medium: 31 Mi-8 Hip

- Light: 3 PZL MI-2 Hoplite ${ }^{17}$

\section{Navy}

The navy had one Naval Force Command (before the annexation of the Crimean Peninsula):

- Black Sea Naval Zone

- Azov Naval Zone

With the loss of the Crimea, the number and type of naval vehicles are unknown or secret at the moment.

17 Miliaty Power Balance 2014, Russia and Eurasia (page 35-37). 


\section{Geostrategy}

\section{Energy}

Over 90 percent of the country's energy consumption comes from Russia. This fact makes the country very dependant and defenceless.

Ukraine is a transit country for gas, which comes from Russia to Europe The diagram below shows the gas network of the country ${ }^{18}$.

\section{Black Sea}

The Black Sea is a significant geostrategical point in the region for both the Russian Federation, Ukraine and Turkey. By observing the Black Sea, they can monitor military and trade ships. Until the loss of the Crimean Peninsula, Ukraine had the longest coastline of the Black Sea.

The Russian Black Sea Fleet is situated in Sevastopol. which is highly important for Russia. Its presence in the area gives Russia a military advantage and it is able to carry out tactical manoeuvers (as it did in the Georgian-Russian conflict).

Its importance has grown since the Syrian conflict, because losing the Tartus fleet in Syria would mean having only one warm-water port in Sevastopol.

\section{Natural Resources}

The country is rich in oil, gas, minerals and has Black Soil which makes the country one of the most productive farming areas in the world.

Significan coal sources and mines can be found in the Donetsk basin (Eastern Ukraine)

18 http://www.eegas.com/images/ukrmap.gif Downloaded: 2015.05.27. 


\section{Situation}

Land Connection between Central- Europe and Russia.

Besides the Carpatheans in the east, the land borders are mainly open and flat (no significant geographical border).

\section{Nuclear facilities}

Ukraine gained worldwide renown in 1985, as a result of the Chernobyl nuclear explosion.. Besides that nuclear reactor, the country has several nuclear power plants. $45,1 \%$ of the overall consumption of the country comes from nuclear sources which are vulnerable to military attacks.

\section{Conclusion}

I hope my paperwork has achieved a result and I have been able to give the reader a bigger insight into the importance of Ukraine. I would like to emphasise that, as it is situated in the the area between Central Europe and Russia, the country has an important role in regional stability.

As we are members of the European Union, we should devote proper attention to areas next to our borders too. Security is only temporary if we do not contribute to maintaining it in the long term. As we can see, next to our borders, war can spark easily and, in order to respond in a situation like this, we have to know the key problems, historical background and the military role of the area.

\section{Bibliography}

Ewan W. Anderson: Global Geopolitical Flashpoints (2000, ISBN: 1-57958-137-4)

Márta Font: History of Ukraine (2006, ISBN: 963-9704-10-5) 
Ágnes Gereben: Post-soviet Scenarios (2014, ISBN: 978-963-227-536-9)

Zoltán Grünhut - Zoltán Vörös: On the doorstep of the transforming world order (2013, ISBN: 978-615-5001-83-3)

V.P. Horbulin, O.F. Byelov, O.v Lytvynenko: Ukraine’s National Security (2010, ISBN: $978-$ 3-643-80045-9)

Gáspár Katkó: "Ukraine: Nation or dream?”(Történelem Portál Volume II., No. 2.,2014. march, ISSN: 2064-0536)

Elena Kropatcheva: Russia's Ukraine Policy against the Background of Russian-Western Competition (2009, ISBN: 978-3-8329-5546-5)

Ann Lewis:The Eu E Ukraine (2002, ISBN: 1-903403-18-9)

Military Power Balance 2014

T.V Paul, James J. Wirtz, Michel Fortmann: Balance of Power (2004, ISBN: 0-8047-5016-5)

Paul Robert Magocsi: Ukraine - An illustrated history (2014, ISBN: 978-1-4426-2756-7)

István Szilágyi:Geopolitics (ISBN:978-615-5001-74-1)

Serhy Yekelchyk: History of Ukraine (2014, ISBN: 978-963-661-702-7) 
